\title{
Australian Journal of \\ REML/BLUP applied to characterize important agronomic traits in segregating generations of bean (Phaseolus vulgaris L.)
}

\author{
Ivan Ricardo Carvalho ${ }^{1}$, José Antonio Gonzalez da Silva ${ }^{1}$, Luiz Leonardo Ferreira ${ }^{2}$, Vinícius Jardel Szareski ${ }^{3}$, \\ Gustavo Henrique Demari ${ }^{3}$, Francine Lautenchleger ${ }^{4}$, Géri Eduardo Meneghello ${ }^{3}$, Ester Mafalda Matter ${ }^{1}$, \\ Devid Araujo Magano ${ }^{1}$, Velci Queiróz de Souza ${ }^{5}$
}

\author{
${ }^{1}$ Universidade Regional do Noroeste do Estado do Rio Grande do Sul, ljuí, RS, Brasil \\ ${ }^{2}$ Centro Universitário de Mineiros, Mineiros, GO, Brasil \\ ${ }^{3}$ Universidade Federal de Pelotas, Capão do Leão, RS, Brasil \\ ${ }^{4}$ Universidade Estadual do Centro Oeste (Unicentro), Guarapuava, PR, Brasil \\ ${ }^{5}$ Universidade Federal do Pampa, São Gabriel, RS, Brasil
}

*Corresponding authors: carvalho.irc@gmail.com

\section{Abstract}

The objective of this work was to estimate and predict the genetic gains through the REML/BLUP methodology for the characters of agronomic interest of common black beanas at segregating generations. The experiments were conducted in 2015,2016 and 2017 in experimental design consisted of augmented blocks in four replicates. Superior genetic variability was identified for the first pod insertion height and plant height in the $\mathrm{F}_{4}$ segregating generation. For the number of pods, seeds and seed mass per plant, genetic contribution superior to the phenotype is expressed in $\mathrm{F}_{3}$ segregating generation. The prediction of genetic value defines that the number of pods, seeds and seed mass per plant can be potentiated in $F_{2}$ segregating generation by selection of population 26 , selection of $F_{3}$ families 64 and $49, F_{4}$ families 33 and 19. Through the estimations and genetic predictions of the characters measured in the segregating generations $F_{2}, F_{3}$ and $F_{4}$ it is possible to define six multivariate genetic profiles. These strategies can be used in quantitative genetic studies aimed at increasing the production of common black bean seeds.

Keywords: Phaseolus vulgaris L.breeding, produticon seeds, yield compounds.

Abbreviations: REML_restricted maximum likelihood; BLUP_Best linear unbiased prediction;LRT_Deviance analysis; FPI_first pod insertion height; PH_ plant height; SMP_seed mass per plant; NPP_number of pods per plant; NSP_number of seeds per plant.

\section{Introduction}

The common bean (Phaseolus vulgaris L.) is one of the most consumed leguminous in the world, and its importance is associated with providing essential nutrients, proteins and minerals (Schmutz et al., 2014). There is an average national production of 3.2 million tonnes, and Brazil is the largest producer and consumer of common bean, however, yield in the country $\left(1,050 \mathrm{~kg} \mathrm{ha}^{-1}\right)$ is still considered low (Conab, 2018). Although the crop has attracted the interest of large producers that can reach yields around $3,000 \mathrm{~kg} \mathrm{ha}^{-1}$. The average low yield of the crop may be due to the predominance of small producers with access to few technological resources (Moura and Brito, 2015).

At the present time, bean breeding programs seek to obtain productive genotypes, upright growth, good commercial appearance of the beans and tolerance to the main diseases that affect the crop (Miklaset al., 2006; Silva et al., 2009; Meloet al., 2010; Rocha et al., 2012). Characteristics such as the first pod insertion height, plant height, number of pods per plant, number of seeds per plant, yield and plant architecture are controlled by the joint expression of several genes that undergo large environmental effects (Moreto et al., 2007; Szareski et al., 2015).

The selection of the best parents, populations and segregating families allow the discarding of genotypes with low genetic potential, this can increase the efficiency of the human and financial resources involved in the selection activity (Rocha et al., 2013, Carvalho et al., 2016). In order to perform selection along the segregating generations, it is necessary to use sophisticated methodologies capable of capitalizing on genetic and environmental effects, as well as estimating and predicting the ranking of the best genotypes (Szareski et al., 2017, Carvalho et al., 2017).

The REML/BLUP methodology allows more accurate and unbiased prediction of the genotypic values of the evaluated genotypes, provides information inherent to individuals within populations and derived families that are selected free of the effects of environment (Resende, 2007; Resende et al., 2015a). In order to obtain the best linear unbiased 
prediction (BLUP) it is necessary to provide the variance components and genetic parameters, but in some practical situations there is no previous knowledge of such components, and it is necessary to estimate them. The application of restricted maximum likelihood (REML) is defined as the ideal procedure to estimate the components and fractionate the total variation of a given character. In this context, the objective of this work was to estimate and predict the genetic gains through the REML/BLUP methodology for the characters of agronomic interest of common black bean as a function of the segregating generations.

\section{Results and discussion}

\section{Variance components and genetic parameters}

Deviance analysis (LRT) revealed a $5 \%$ probability by the chisquare test $\left(\mathrm{X}^{2}\right)$ significance for the characters first pod insertion height (FPI), plant height (PH), seed mass per plant (SMP), number of pods per plant (NPP) and number of seeds per plant (NSP) for the $F_{2}, F_{3}$ and $F_{4}$ segregating generations (Table 1).

The phenotypic expression of the first pod insertion height (FPI) was dependent not only on the total genetic effects, but on the segregating generation in question. Therefore, it was identified that this character is controlled by $36.6 \%\left(F_{2}\right)$, $32.4 \%\left(\mathrm{~F}_{3}\right)$ and $62.8 \%\left(\mathrm{~F}_{4}\right)$ of additive and non-additive genetic effects, and that the breeding generations advance together with the targeted selections, phenotypic manifestations are primarily controlled by genetic effects. For this character the advance of the generations allowed that the broad sense heritability $\left(\mathrm{H}^{2}\right)$ was increased, but it is possible to verify that the first pod insertion height in generation $\mathrm{F}_{3}$ was affected by $68.0 \%$ of effects attributed to the edaphoclimatic conditions of the environment. When analyzing the general mean of the character, it was possible to verify that there was an increase of $1.83 \mathrm{~cm}$ at first pod insertion height $\left(F_{2}-F_{4}\right)$ due to the selection cycles directed to the plants and higher families.

The plant height $(\mathrm{PH})$ revealed that, in the $\mathrm{F}_{2}$ generation, its phenotypic expression was controlled by $48.6 \%$ due to the genetic effects, the generations advance allowed the increase of the genetic contribution to the phenotype $\left(\mathrm{F}_{3}\right.$ : $56.8 \%$ and $\left.F_{4}: 72.1 \%\right)$, under these conditions, it is defined that the directed selections allowed $\left(F_{2}-F_{4}\right)$ a $23.5 \%$ increase in the genetic contribution to the phenotype. In relation to the broad sense heritability $\left(\mathrm{H}^{2}\right)$ the parameter was increased over the generations, however, in $F_{4}$ families it was verified that the effects of environment influence in $27 \%$ the plant height. Accuracy is increased over the generations being classified as high in $\mathrm{F}_{4}$. In relation to the increase of the average of this character, it is evident that for $23.5 \%$ increase of the genetic fraction to the phenotype it is possible to obtain plants $2.5 \mathrm{~cm}$ higher, it is established that for each $1 \mathrm{~cm}$ of modifications in the phenotype, 9.4\% of modifications are necessary in the total genotypic fraction.

The seed mass per plant (SMP) showed superiority of the contribution of the genetic fraction to the phenotype in the $F_{2}$ generation (58.5\%), these magnitudes decreased $32.8 \%$ between the $F_{2}$ and $F_{4}$ generations, this is due to the directed selections have provided the controlled restriction of the genetic variability for this character in $\mathrm{F}_{3}$ and $\mathrm{F}_{4}$, since the families in these generations were based on the premise of the maximum homogeneity within the family and between families the selection of those that were superior was prioritized.

The number of pods per plant (NPP) presented the maximum contribution of the genetic variation to the phenotype in generation $F_{3}(51.5 \%)$, between the generations $F_{2}$ (populations) and $F_{4}$ (families), the selections targeting higher genotypes allowed the increase of $10.7 \%$ of the determining genetic fraction to the number of pods per plant, and it is proven in generation $F_{2}$ that this character was influenced by $85 \%$ due to the effects of the environment.

The number of seeds per plant (NSP) revealed the maximum genetic variability in the $\mathrm{F}_{3}$ generation, where $70.8 \%$ of the magnitude of seeds produced per plant were determined by the genetic constitution of the segregating family, however, the selection strategies were efficient throughout the generations of $F_{2}$ to $F_{4}$, since they provided a $17.4 \%$ increase in the genetic contribution to the number of seeds. Considering the parameter of broad sense heritability, it was possible to verify that in the advanced generations $\left(F_{4}\right)$ the number of seeds per plant is influenced by $74.4 \%$ due to the environment, however, this response can not be visualized through the general average of this character, in this way, the selections should be based not only on the average value but on the genetic parameters.

\section{Best linear unbiased prediction (BLUP)}

This methodology is supported by variance components and genetic parameters (REML) where the estimates obtained are used to predict the genetic value (BLUP), which will later be used to rank the best genotypes through their genetic value with no effect of the environment, this allows the selection of the best genotypes to be reliable and accurate with smaller biases attributed to the non-controllable distortions resulting from the environment. The predictions were based on the first pod insertion height (FPI), plant height $(\mathrm{PH})$, number of pods per plant (NPP), number of seeds per plant (NSP) and seed mass per plant (SMP), and the 33 segregating $F 2$ populations were ranked and related according to the performance of the BRS Esplendor (BE), BRS Supremo (BS) and IPR Tiziu (IT) control genotypes.

The first pod insertion height (FPI) showed that $42 \%$ of the segregating $F_{2}$ populations were higher (Table 2) than the commercial ones, which were $3,4,24,15,23,31,21,27,26$, 20, 2, 33, 32 and 18. Higher predicted genetic gains can be obtained by selecting population 3 that will result in a genetic increment of $9.18 \%$ for first pod insertion height, resulting in increases of $6.01 \mathrm{~cm}$ and plants in the subsequent generation with $15.95 \mathrm{~cm}$.

Plant height $(\mathrm{PH})$ revealed that $45.5 \%$ of the segregating $F_{2}$ populations were higher than the commercial controls, comprising population $9,31,3,4,26,33,18,23,24,30,5$, $21,2,22$ and 10 . Higher genetic gains can be obtained by selection directed at population 9 that will result in a genetic increase of $6.88 \%$, this selection increases by $23.39 \mathrm{~cm}$ the magnitude of the character and in the next generation families from this population would express $46.18 \mathrm{~cm}$ in its phenotype. 
The number of pods per plant (NPP) defined that $48.5 \%$ of the $F_{2}$ populations evaluated were higher than commercial controls, which were 26, 9, 10, 18, 29, 4, 5, 21, 3, 22, 7, 23, $12,17,30$ and 31 . Superiority in genetic gains can be obtained by selecting the population 29 that allows increment of $7.90 \%$, that is, due to the targeted selection it will be possible to increase in 2.4 pods per plant and in the next generation the plants will show on average 10.63 pods. As for the number of seeds per plant (NSP), it was found that $42.4 \%$ of the $F_{2}$ populations evaluated were superior to commercial controls, this characteristic follows a tendency similar to the number of pods per plant, where greater genetic gains are obtained by selecting the population 26 which results in genetic increases of $9.66 \%$ with additions of 11.4 seeds per plant and in the next generation it will be possible to obtain plants with 42.9 seeds.

The seed mass per plant (SMP) showed that $36.4 \%$ of the $F_{2}$ populations were superior to the commercial ones, with the potential to identify plants and later families that will later generate a more productive genotype, under these conditions, it was identified that the number of pods per plant, number of seeds per plant and seed mass were higher in the population 26 and this was defined as high potential, being higher for the components of the seed yield with genetic gains of $8.74 \%$ and increase of $7.05 \mathrm{~g}$ of seeds per plant.

The $F_{3}$ generation consisted of 63 families of common black bean from the segregating $F_{2}$ populations (Table 3 and 4). These families were selected according to the criterion of flowering homogeneity at plant level, upright growth and seed color. In this context, genetic estimates and predictions were based on standard segregation, assuming that in this generation $25 \%$ of the individuals belonging to his family present in heterozygosis, being possible that for some characters of quantitative inheritance there are effects of non-additive genetic deviations.

The first pod insertion height (FPI) showed that $47.8 \%$ of the segregating $F_{3}$ families were higher than the commercial controls (Table 3). These were 34, 10, 24, 3, 36, 37, 38, 67, $23,55,35,33,4,9,49,65,56,21,28,5,7,20,50,11,48,58$, $62,63,64,29,2,6$ and 22 . However, higher genetic gains can be obtained by selecting family 34 with increases of $3.65 \%$ corresponding to $5.3 \mathrm{~cm}$, for the next generation the plants would obtain first pod insertion height of $16.01 \mathrm{~cm}$, this targeted selection could lead to decreases to the productive potential of seeds, because the first pod insertion height around $10 \mathrm{~cm}$ is prioritized, so that it is possible to express the maximum number of flowers, pods and branches in the stem of the bean, therefore, agronomically the selection for this character should be directed to families 2, 6 and 22 as these revealed phenotype up to $11 \mathrm{~cm}$ first pod insertion height.

Plant height $(\mathrm{PH})$ followed similar trend for the first pod insertion height relative to the higher $\mathrm{F}_{3}$ family; however, the selection should be directed to families $66,23,64,37$ and 49 which express genetic increase of 13 to $15 \mathrm{~cm}$ in height due to targeted selection, being possible to obtain plants greater than $35 \mathrm{~cm}$ in the subsequent crop. The number of pods per plant (NPP) showed that $36.2 \%$ of the segregating $F_{3}$ families were higher than the commercial controls (Table 4), which were $64,49,47,8,50,51,36,14,2,26,62,9,63,43,21,25$, $37,42,40,45,52,66,24,35$ and 11 . The highest genetic gains are obtained by selection directed to the family 64 where $7.56 \%$ of the gains are obtained, this will result in an increase of 13.8 pods per plant and in the next crop it will be possible to obtain plants with 23.06 pods.

The number of seeds per plant (NSP) revealed that $29 \%$ of the $\mathrm{F}_{3}$ families were superior to the commercial controls, being these, $64,49,51,47,8,50,36,62,2,9,48,63,21,37$, $10,26,52,3,35$ and 1 . This characteristic follows a tendency similar to the number of pods per plant, where the highest genetic gains were obtained by family 64 with $6.20 \%$, since the directed selection could increase in 95.69 seeds per plant and for new crops and the plants could express 126.49 seeds.

Seed mass per plant (SMP) revealed that $33 \%$ of the segregating $F_{3}$ families were superior to commercial controls, which express the potential to generate genotypes with high seed yield potential, being 49, 64, 8, 36, 51, 47, 50, $26,27,25,30,37,9,40,62,10,5,43,21,63,42,2$ and 55. High gains for this character can be obtained by targeting families 64 and 49 that show genetic increments higher than $6.5 \%$ and correspond to an increase of 10 grams of seeds per plant, with the selection of these families the plants could express more than 20 grams of seeds on average.

In relation to the $\mathrm{F}_{4}$ segregating generation, 41 families were evaluated, where a theoretical level of $12.5 \%$ of heterozygous individuals within the family was considered. The families that make up this generation were selected according to the criteria of flowering homogeneity at plant level, upright growth, seed color, number and seed mass per plant (Table 5). As for the first pod insertion height (FPI), it was verified that $48.8 \%$ of the tested families were superior to the commercial genotypes assumed as controls, in this context, even though there were genetic gains of $7.13 \%$ for this character through the selection of the best family, however, this should approximate the agronomic ideotype that the controls express, so the selection should be directed to families 33,36 and 20 that evidenced first pod insertion height from 16 to $17 \mathrm{~cm}$.

Plant height $(\mathrm{PH})$ showed that $34.1 \%$ of the $\mathrm{F}_{3}$ families tested were superior to the commercial genotypes, being these, 32 , $16,19,20,9,3,8,2,21,1,12,13,22$ and 17. The families 32 and 16 expressed a genetic gain greater than $5.5 \%$ corresponding to an increase of $35.6 \mathrm{~cm}$ and plants that meet the agronomic standard with a height of around $60 \mathrm{~cm}$. The number of pods per plant (NPP) showed that $41.5 \%$ of the families were superior to commercial controls, being these, 33, 19, 13, 3, 21, 6, 4, 31, 22, 1, 26, 40, 35, 17, 5, 34 and 38. Higher genetic gains can be obtained by selecting families 33 and 19 which result in an increase of $5 \%$ and corresponds to the addition of 3 pods per plant.

For the number of seeds per plant (NSP), it was verified, $48.8 \%$ of the $F_{3}$ families were superior to the commercial genotypes, being these 19, 1, 13, 3, 21, 33, 2, 22, 9, 31, 8, 17, $6,16,34,35,39,4,40$ and 26 . Higher gains were obtained through family 19 that results in a genetic increment of $7.64 \%$, which represents an increase of 21 seeds per plant and families with 52.9 seeds per plant on average. The seed mass per plant (SMP) was found in $53.7 \%$ of the F3 families superior to the commercial genotypes, therefore, there are tendencies and conditions to obtain highly productive genotypes through the families $6,19,31,33,34,15,40,21$, $1,4,22,3,26,17,13,35,41,18,38,39,29$ and 25 . Superior genetic gains for seed yield can be obtained by directing selection to families 6,19 and 31 that showed gains higher 
Table 1. Estimation of variance components and genetic parameters (RELM) for the first pod insertion height (FPI), plant height $(\mathrm{PH})$, total seed mass per plant (SMP), number of pods per plant (NPP), number of seeds per plant (NSP), for the segregating generations F2, F3 and F4 of common black bean.

\begin{tabular}{|c|c|c|c|}
\hline & \multicolumn{3}{|c|}{ Segregatinggenerations } \\
\hline & $\mathrm{F}_{2}$ & $\mathrm{~F}_{3}$ & $\mathrm{~F}_{4}$ \\
\hline \multicolumn{4}{|c|}{$\mathrm{FPI}(\mathrm{cm})$} \\
\hline Deviance (LRT) & $*$ & $*$ & $*$ \\
\hline$V_{P}$ & 18.35 & 23.17 & 36.20 \\
\hline $\mathrm{V}_{\mathrm{G}}$ & 6.73 & 7.51 & 22.74 \\
\hline $\mathrm{H}^{2}$ & 0.36 & 0.32 & 0.62 \\
\hline$C^{2}$ & 0.09 & 0.00 & 0.00 \\
\hline$A_{c}$ & 0.60 & 0.56 & 0.79 \\
\hline Mean & 9.94 & 10.62 & 11.77 \\
\hline \multicolumn{4}{|c|}{$\mathrm{PH}(\mathrm{cm})$} \\
\hline Deviance (LRT) & $*$ & $*$ & $*$ \\
\hline$V_{P}$ & 323.94 & 103.51 & 428.63 \\
\hline$V_{G}$ & 157.57 & 58.87 & 309.45 \\
\hline $\mathrm{H}^{2}$ & 0.48 & 0.56 & 0.72 \\
\hline$C^{2}$ & 0.01 & 0.00 & 0.02 \\
\hline $\mathrm{A}_{C}$ & 0.69 & 0.75 & 0.84 \\
\hline Mean & 22.78 & 21.18 & 25.10 \\
\hline \multicolumn{4}{|c|}{ SMP (g) } \\
\hline Deviance (LRT) & $*$ & $*$ & $*$ \\
\hline$V_{P}$ & 13.54 & 12.57 & 13.57 \\
\hline $\mathrm{V}_{\mathrm{G}}$ & 7.93 & 6.68 & 3.48 \\
\hline $\mathrm{H}^{2}$ & 0.58 & 0.53 & 0.25 \\
\hline$C^{2}$ & 0.02 & 0.03 & 0.00 \\
\hline$A_{c}$ & 0.76 & 0.53 & 0.50 \\
\hline Mean & 11.28 & 10.33 & 11.32 \\
\hline \multicolumn{4}{|c|}{ NPP (units) } \\
\hline Deviance (LRT) & $*$ & $*$ & $*$ \\
\hline$V_{p}$ & 16.20 & 18.03 & 16.23 \\
\hline$V_{G}$ & 2.46 & 9.30 & 4.20 \\
\hline $\mathrm{H}^{2}$ & 0.15 & 0.51 & 0.25 \\
\hline$C^{2}$ & 0.00 & 0.02 & 0.01 \\
\hline$A_{C}$ & 0.39 & 0.71 & 0.50 \\
\hline Mean & 8.17 & 9.20 & 8.43 \\
\hline \multicolumn{4}{|c|}{ NSP (units) } \\
\hline Deviance (LRT) & $*$ & $*$ & $*$ \\
\hline$V_{P}$ & 327.50 & 499.66 & 294.66 \\
\hline$V_{G}$ & 40.52 & 353.90 & 78.85 \\
\hline $\mathrm{H}^{2}$ & 0.12 & 0.70 & 0.26 \\
\hline$C^{2}$ & 0.00 & 0.00 & 0.09 \\
\hline$A_{C}$ & 0.35 & 0.84 & 0.51 \\
\hline Mean & 31.48 & 30.79 & 31.95 \\
\hline
\end{tabular}

* Deviance (LRT) significant at $5 \%$ of probability by $\mathrm{x}^{2}$ test; ${ }^{\mathrm{ns}}$ Deviance (LRT) not significant at $5 \%$ of probability by $\mathrm{x}^{2}$ test; $\mathrm{V}_{\mathrm{p}}$ : phenotypic variance, $\mathrm{V}_{\mathrm{G}}$ : genetic variance; $\mathrm{H}^{2}$ : broad sense heritability; $C^{2}$ : coefficient of determination of plot effects; $A_{c}$ : accuracy; Mean: overall mean of the experiment.

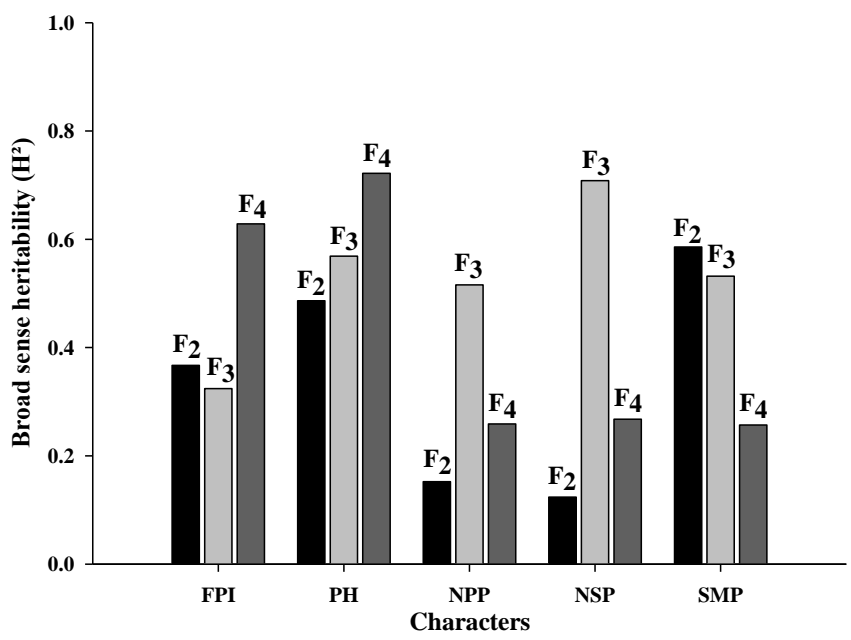

Fig 1. Broad sense heritability $\left(\mathrm{H}^{2}\right)$ estimated for the first pod insertion height (FPI), plant height (PH), number of pods per plant (NPP), number of seeds per plant (NSP), total seed mass per plant (SMP). 
Table 2. Predictions for the best linear unbiased prediction (BLUP) referring to the first pod insertion height (FPI), plant height (PH), number of pods per plant (NPP), number of seeds per plant (NSP), total seed mass per plant (SMP), estimated for $33 F_{2}$ segregating populations of common black bean.

\begin{tabular}{|c|c|c|c|c|c|c|c|c|c|c|}
\hline \multirow[b]{2}{*}{$\mathrm{R}^{*}$} & \multicolumn{2}{|c|}{ FPI } & \multicolumn{2}{|c|}{$\mathrm{PH}$} & \multicolumn{2}{|c|}{ NPP } & \multicolumn{2}{|c|}{ NSP } & \multicolumn{2}{|c|}{ SMP } \\
\hline & $P$ & $\mathrm{G}$ & $P$ & $\mathrm{G}$ & $P$ & $\mathrm{G}$ & $P$ & $\mathrm{G}$ & $P$ & $\mathrm{G}$ \\
\hline 1 & 3 & 9.18 & 9 & 6.88 & 26 & 7.90 & 26 & 9.66 & 26 & 8.74 \\
\hline 2 & 4 & 7.23 & 31 & 6.46 & 9 & 7.01 & 9 & 8.16 & 7 & 8.16 \\
\hline 3 & 24 & 6.51 & 3 & 6.14 & 10 & 6.6 & 4 & 6.77 & 10 & 7.90 \\
\hline 4 & 15 & 5.87 & 4 & 5.87 & 18 & 6.34 & 23 & 5.86 & 9 & 6.83 \\
\hline 5 & 23 & 5.43 & 26 & 5.56 & 29 & 5.84 & 18 & 5.3 & 30 & 6.11 \\
\hline 6 & 31 & 5.04 & 33 & 5.17 & 4 & 5.39 & 22 & 4.88 & 21 & 5.61 \\
\hline 7 & 21 & 4.67 & 18 & 4.88 & 5 & 4.91 & 5 & 4.57 & 18 & 5.16 \\
\hline 8 & 27 & 4.35 & 23 & 4.65 & 21 & 4.53 & 3 & 4.33 & 20 & 4.67 \\
\hline 9 & 26 & 4.05 & 24 & 4.47 & 3 & 4.19 & 30 & 4.08 & 23 & 4.23 \\
\hline 10 & 20 & 3.80 & 30 & 4.24 & 22 & 3.89 & 10 & 3.87 & 5 & 3.85 \\
\hline 11 & 2 & 3.58 & 5 & 4.04 & 7 & 3.63 & 21 & 3.65 & 19 & 3.53 \\
\hline 12 & 33 & 3.39 & 21 & 3.76 & 23 & 3.40 & 33 & 3.39 & 29 & 3.24 \\
\hline 13 & 32 & 3.18 & 2 & 3.51 & 12 & 3.16 & 19 & 3.14 & BE & 2.99 \\
\hline 14 & 18 & 2.96 & 22 & 3.3 & 17 & 2.94 & 7 & 2.93 & IT & 2.78 \\
\hline 15 & BE & 2.76 & 10 & 3.08 & 30 & 2.76 & IT & 2.73 & BS & 2.59 \\
\hline 16 & BS & 2.59 & BS & 2.89 & 31 & 2.60 & BE & 2.56 & 33 & 2.42 \\
\hline 17 & BE & 2.43 & IT & 2.72 & BS & 2.44 & BS & 2.41 & 3 & 2.26 \\
\hline 18 & 30 & 2.29 & $\mathrm{BE}$ & 2.57 & $\mathrm{BE}$ & 2.31 & 29 & 2.27 & 4 & 2.10 \\
\hline 19 & 25 & 2.16 & 17 & 2.40 & IT & 2.19 & 20 & 2.15 & 25 & 1.95 \\
\hline 20 & 17 & 2.03 & 32 & 2.23 & 19 & 2.07 & 2 & 2.02 & 27 & 1.80 \\
\hline 21 & 16 & 1.91 & 27 & 2.06 & 33 & 1.96 & 31 & 1.89 & 14 & 1.66 \\
\hline 22 & 13 & 1.80 & 12 & 1.89 & 28 & 1.85 & 27 & 1.76 & 15 & 1.52 \\
\hline 23 & 29 & 1.69 & 29 & 1.72 & 20 & 1.74 & 24 & 1.65 & 2 & 1.40 \\
\hline 24 & 8 & 1.58 & 25 & 1.55 & 24 & 1.6 & 28 & 1.54 & 28 & 1.28 \\
\hline 25 & 14 & 1.48 & 8 & 1.40 & 8 & 1.47 & 12 & 1.43 & 8 & 1.17 \\
\hline 26 & 1 & 1.35 & 7 & 1.24 & 14 & 1.33 & 32 & 1.29 & 16 & 1.07 \\
\hline 27 & 9 & 1.23 & 20 & 1.10 & 2 & 1.2 & 14 & 1.15 & 11 & 0.97 \\
\hline 28 & 19 & 1.11 & 28 & 0.96 & 27 & 1.07 & 17 & 1.02 & 13 & 0.87 \\
\hline 29 & 6 & 0.99 & 19 & 0.83 & 1 & 0.93 & 8 & 0.89 & 24 & 0.76 \\
\hline 30 & 10 & 0.87 & 16 & 0.70 & 25 & 0.79 & 1 & 0.76 & 32 & 0.65 \\
\hline 31 & 12 & 0.75 & 14 & 0.58 & 32 & 0.66 & 25 & 0.63 & 17 & 0.55 \\
\hline 32 & 7 & 0.63 & 15 & 0.46 & 16 & 0.53 & 13 & 0.50 & 12 & 0.45 \\
\hline 33 & 5 & 0.50 & 6 & 0.35 & 11 & 0.39 & 16 & 0.37 & 6 & 0.35 \\
\hline 34 & 28 & 0.36 & 13 & 0.23 & 13 & 0.26 & 11 & 0.25 & 22 & 0.25 \\
\hline 35 & 22 & 0.22 & 1 & 0.11 & 6 & 0.13 & 15 & 0.13 & 31 & 0.14 \\
\hline 36 & 11 & 0.00 & 11 & 0.00 & 15 & 0.00 & 6 & 0.00 & 1 & 0.00 \\
\hline
\end{tabular}

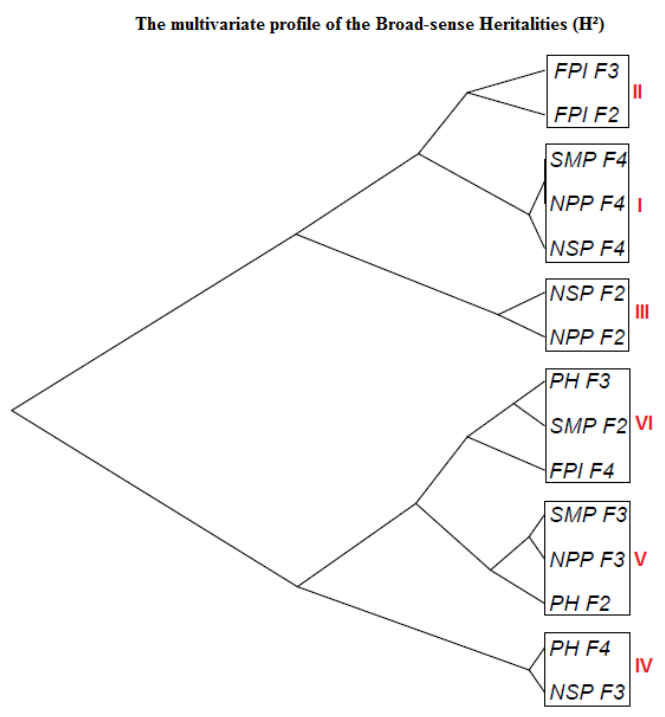

Fig 2. Dendrogram referring to the multivariate profile of the broad-sense heritabilities $\left(\mathrm{H}^{2}\right)$ of the contrasting characters of the segregating generations $F_{2}, F_{3}$ and $F_{4}$ of common black bean. First pod insertion height (FPI), plant height (PH), number of pods per plant (NPP), number of seeds per plant (NSP), total seed mass per plant (SMP). 
Table 3. Predictions for the best linear unbiased prediction (BLUP) regarding the first pod insertion height (FPI), estimated plant height $(\mathrm{PH})$ for $69 \mathrm{~F}_{3}$ segregating families of common black bean.

\begin{tabular}{|c|c|c|c|c|c|c|c|c|c|c|c|c|c|c|}
\hline \multirow[b]{2}{*}{$\mathrm{R}^{*}$} & \multicolumn{2}{|c|}{ FPI } & \multicolumn{2}{|c|}{$\mathrm{PH}$} & \multirow[b]{2}{*}{$R$} & \multicolumn{2}{|c|}{ FPI } & \multicolumn{2}{|c|}{$\mathrm{PH}$} & \multirow[b]{2}{*}{$\mathrm{R}$} & \multicolumn{2}{|c|}{ FPI } & \multicolumn{2}{|c|}{$\mathrm{PH}$} \\
\hline & $\mathrm{F}$ & G & $\mathrm{F}$ & G & & $\mathrm{F}$ & G & $\mathrm{F}$ & $\mathrm{G}$ & & $\mathrm{F}$ & $\mathrm{G}$ & $\mathrm{F}$ & G \\
\hline 1 & 34 & 3.65 & 66 & 3.48 & 25 & 48 & 1.67 & 2 & 1.79 & 49 & 60 & 0.76 & 46 & 0.74 \\
\hline 2 & 10 & 3.56 & 23 & 3.38 & 26 & 58 & 1.62 & 63 & 1.74 & 50 & 54 & 0.72 & 44 & 0.70 \\
\hline 3 & 24 & 3.46 & 64 & 3.32 & 27 & 62 & 1.57 & 7 & 1.70 & 51 & 27 & 0.69 & 40 & 0.67 \\
\hline 4 & 3 & 3.41 & 37 & 3.18 & 28 & 63 & 1.53 & 48 & 1.65 & 52 & 30 & 0.65 & 41 & 0.63 \\
\hline 5 & 36 & 3.25 & 49 & 3.06 & 29 & 64 & 1.48 & 6 & 1.6 & 53 & 45 & 0.62 & 17 & 0.60 \\
\hline 6 & 37 & 3.09 & 67 & 2.96 & 30 & 29 & 1.44 & 34 & 1.56 & 54 & 25 & 0.59 & 26 & 0.56 \\
\hline 7 & 38 & 2.98 & 51 & 2.89 & 31 & 2 & 1.41 & 52 & 1.51 & 55 & 32 & 0.56 & 29 & 0.53 \\
\hline 8 & 67 & 2.88 & 3 & 2.81 & 32 & 6 & 1.37 & 43 & 1.47 & 56 & 52 & 0.53 & 59 & 0.50 \\
\hline 9 & 23 & 2.78 & 62 & 2.73 & 33 & 22 & 1.33 & IT & 1.42 & 57 & 40 & 0.49 & 60 & 0.47 \\
\hline 10 & 55 & 2.69 & 47 & 2.66 & 34 & IT & 1.30 & BS & 1.38 & 58 & 44 & 0.46 & 56 & 0.44 \\
\hline 11 & 35 & 2.60 & 10 & 2.59 & 35 & BE & 1.26 & BE & 1.34 & 59 & 42 & 0.43 & 31 & 0.40 \\
\hline 12 & 33 & 2.52 & 8 & 2.50 & 36 & BS & 1.22 & 55 & 1.30 & 60 & 15 & 0.40 & 58 & 0.37 \\
\hline 13 & 4 & 2.45 & 25 & 2.42 & 37 & 66 & 1.19 & 28 & 1.25 & 61 & 39 & 0.37 & 18 & 0.34 \\
\hline 14 & 9 & 2.38 & 65 & 2.35 & 38 & 31 & 1.15 & 33 & 1.21 & 62 & 41 & 0.34 & 30 & 0.31 \\
\hline 15 & 49 & 2.32 & 50 & 2.28 & 39 & 19 & 1.11 & 68 & 1.16 & 63 & 8 & 0.31 & 57 & 0.28 \\
\hline 16 & 65 & 2.24 & 35 & 2.22 & 40 & 57 & 1.08 & 19 & 1.11 & 64 & 17 & 0.28 & 15 & 0.24 \\
\hline 17 & 56 & 2.16 & 38 & 2.17 & 41 & 61 & 1.04 & 11 & 1.07 & 65 & 53 & 0.25 & 61 & 0.21 \\
\hline 18 & 21 & 2.08 & 9 & 2.12 & 42 & 68 & 1.01 & 42 & 1.02 & 66 & 18 & 0.22 & 54 & 0.18 \\
\hline 19 & 28 & 2.02 & 24 & 2.07 & 43 & 43 & 0.98 & 36 & 0.98 & 67 & 59 & 0.19 & 39 & 0.15 \\
\hline 20 & 5 & 1.95 & 5 & 2.02 & 44 & 46 & 0.94 & 20 & 0.94 & 68 & 12 & 0.15 & 32 & 0.12 \\
\hline 21 & 7 & 1.89 & 4 & 1.97 & 45 & 1 & 0.90 & 14 & 0.89 & 69 & 16 & 0.12 & 53 & 0.09 \\
\hline 22 & 20 & 1.83 & 22 & 1.93 & 46 & 47 & 0.86 & 27 & 0.85 & 70 & 13 & 0.08 & 16 & 0.06 \\
\hline 23 & 50 & 1.77 & 1 & 1.88 & 47 & 51 & 0.83 & 45 & 0.82 & 71 & 14 & 0.04 & 12 & 0.03 \\
\hline 24 & 11 & 1.72 & 21 & 1.84 & 48 & 26 & 0.79 & 69 & 0.78 & 72 & 69 & 0.00 & 13 & 0.00 \\
\hline
\end{tabular}

* R: ranking; P: $F_{3}$ segregating population; G: predicted genetic gain; BE: BRS Splendor control; BS: BRS Supreme control; IT: IPR Tiziu control

Table 4. Predictions for the best linear unbiased prediction (BLUP) for number of pods per plant (NPP), number of seeds per plant (NSP), total seed mass per plant (SMP) estimated for $69 \mathrm{~F}_{3}$ segregating families of common black beans.

\begin{tabular}{|c|c|c|c|c|c|c|c|c|c|c|c|c|c|c|c|c|c|c|c|c|}
\hline \multirow[b]{2}{*}{$\mathrm{R}$} & \multicolumn{2}{|c|}{ NPP } & \multicolumn{2}{|c|}{ NSP } & \multicolumn{2}{|c|}{ SMP } & \multirow[b]{2}{*}{$\mathrm{R}$} & \multicolumn{2}{|c|}{ NPP } & \multicolumn{2}{|c|}{ NSP } & \multicolumn{2}{|c|}{ SMP } & \multirow[b]{2}{*}{$\mathrm{R}$} & \multicolumn{2}{|c|}{ NPP } & \multicolumn{2}{|c|}{ NSP } & \multicolumn{2}{|c|}{ SMP } \\
\hline & $\mathrm{F}$ & G & $\mathrm{F}$ & $G$ & $\mathrm{~F}$ & $G$ & & $\mathrm{~F}$ & $\mathrm{G}$ & $\mathrm{F}$ & $G$ & $\mathrm{~F}$ & $G$ & & $\mathrm{~F}$ & $\mathrm{G}$ & $\mathrm{F}$ & $G$ & $\mathrm{~F}$ & $\mathrm{G}$ \\
\hline 1 & 64 & 7.56 & 64 & 8.20 & 49 & 7.02 & 25 & 11 & 1.41 & 40 & 1.32 & BE & 0.19 & 49 & 7 & 0.53 & 69 & 0.45 & 57 & 0.07 \\
\hline 2 & 49 & 6.44 & 49 & 6.74 & 64 & 0.95 & 26 & BE & 1.35 & 66 & 1.27 & IT & 0.19 & 50 & 28 & 0.51 & 13 & 0.42 & 22 & 0.07 \\
\hline 3 & 47 & 5.27 & 51 & 5.62 & 8 & 0.78 & 27 & BS & 1.30 & 24 & 1.21 & 59 & 0.18 & 51 & 32 & 0.48 & 39 & 0.40 & 38 & 0.07 \\
\hline 4 & 8 & 4.59 & 47 & 4.93 & 36 & 0.69 & 28 & IT & 1.26 & 30 & 1.16 & 45 & 0.17 & 52 & 69 & 0.46 & 57 & 0.38 & 33 & 0.06 \\
\hline 5 & 50 & 4.09 & 8 & 4.50 & 51 & 0.62 & 29 & 10 & 1.21 & 45 & 1.12 & 31 & 0.17 & 53 & 46 & 0.44 & 61 & 0.36 & 39 & 0.06 \\
\hline 6 & 51 & 3.74 & 50 & 4.11 & 47 & 0.57 & 30 & 48 & 1.17 & 65 & 1.07 & 4 & 0.16 & 54 & 67 & 0.41 & 53 & 0.33 & 67 & 0.06 \\
\hline 7 & 36 & 3.47 & 36 & 3.77 & 50 & 0.53 & 31 & 30 & 1.12 & 43 & 1.03 & 32 & 0.15 & 55 & 15 & 0.39 & 60 & 0.31 & 53 & 0.05 \\
\hline 8 & 14 & 3.18 & 62 & 3.44 & 26 & 0.50 & 32 & 39 & 1.08 & 42 & 0.99 & 48 & 0.15 & 56 & 16 & 0.36 & 44 & 0.29 & 60 & 0.05 \\
\hline 9 & 2 & 2.94 & 2 & 3.16 & 27 & 0.46 & 33 & 31 & 1.04 & 5 & 0.94 & 29 & 0.14 & 57 & 12 & 0.34 & 46 & 0.27 & 68 & 0.05 \\
\hline 10 & 26 & 2.75 & 9 & 2.93 & 25 & 0.42 & 34 & 4 & 1.00 & 11 & 0.90 & 6 & 0.14 & 58 & 41 & 0.32 & 55 & 0.25 & 46 & 0.04 \\
\hline 11 & 62 & 2.59 & 48 & 2.74 & 30 & 0.39 & 35 & 5 & 0.97 & 4 & 0.87 & 28 & 0.13 & 59 & 60 & 0.29 & 16 & 0.23 & 41 & 0.04 \\
\hline 12 & 9 & 2.45 & 63 & 2.58 & 37 & 0.37 & 36 & 44 & 0.93 & 38 & 0.83 & 14 & 0.13 & 60 & 17 & 0.27 & 19 & 0.21 & 15 & 0.04 \\
\hline 13 & 63 & 2.32 & 21 & 2.43 & 9 & 0.35 & 37 & 65 & 0.89 & 6 & 0.79 & 11 & 0.12 & 61 & 20 & 0.25 & 33 & 0.19 & 19 & 0.03 \\
\hline 14 & 43 & 2.21 & 37 & 2.29 & 40 & 0.33 & 38 & 3 & 0.86 & 23 & 0.76 & 1 & 0.12 & 62 & 33 & 0.23 & 7 & 0.18 & 58 & 0.03 \\
\hline 15 & 21 & 2.10 & 10 & 2.17 & 62 & 0.31 & 39 & 29 & 0.82 & 28 & 0.73 & 52 & 0.12 & 63 & 19 & 0.21 & 15 & 0.16 & 17 & 0.03 \\
\hline 16 & 25 & 2.01 & 26 & 2.05 & 10 & 0.29 & 40 & 6 & 0.79 & 59 & 0.69 & 3 & 0.11 & 64 & 22 & 0.19 & 54 & 0.14 & 16 & 0.02 \\
\hline 17 & 37 & 1.92 & 52 & 1.94 & 5 & 0.28 & 41 & 38 & 0.76 & 31 & 0.66 & 13 & 0.11 & 65 & 61 & 0.16 & 58 & 0.12 & 18 & 0.02 \\
\hline 18 & 42 & 1.85 & 3 & 1.84 & 43 & 0.27 & 42 & 23 & 0.73 & 32 & 0.63 & 24 & 0.10 & 66 & 55 & 0.14 & 41 & 0.10 & 7 & 0.02 \\
\hline 19 & 40 & 1.78 & 35 & 1.74 & 21 & 0.25 & 43 & 59 & 0.70 & 14 & 0.60 & 61 & 0.10 & 67 & 53 & 0.12 & 17 & 0.09 & 12 & 0.02 \\
\hline 20 & 45 & 1.71 & 1 & 1.66 & 63 & 0.24 & 44 & 1 & 0.67 & 67 & 0.57 & 35 & 0.09 & 68 & 54 & 0.09 & 12 & 0.07 & 69 & 0.01 \\
\hline 21 & 52 & 1.64 & IT & 1.58 & 42 & 0.23 & 45 & 13 & 0.64 & 27 & 0.55 & 44 & 0.09 & 69 & 34 & 0.07 & 20 & 0.05 & 54 & 0.01 \\
\hline 22 & 66 & 1.58 & BS & 1.51 & 2 & 0.22 & 46 & 18 & 0.61 & 29 & 0.52 & 23 & 0.09 & 70 & 57 & 0.05 & 18 & 0.04 & 20 & 0.01 \\
\hline 23 & 24 & 1.52 & BE & 1.44 & 55 & 0.21 & 47 & 27 & 0.59 & 22 & 0.49 & 65 & 0.08 & 71 & 58 & 0.03 & 56 & 0.02 & 34 & 0.00 \\
\hline 24 & 35 & 1.47 & 25 & 1.38 & BS & 0.20 & 48 & 68 & 0.56 & 68 & 0.47 & 66 & 0.08 & 72 & 56 & 0.00 & 34 & 0.00 & 56 & 0.00 \\
\hline
\end{tabular}

* R: ranking; P: $F_{3}$ segregating population; G: predicted genetic gain; BE: BRS Splendor control; BS: BRS Supreme control; IT: IPR Tiziu control 
Table 5. Predictions for the best linear unbiased prediction (BLUP) concerning the first pod insertion height (FPI), plant height (PH), number of pods per plant (NPP), number of seeds per plant (NSP), total seed mass per plant (SMP), estimated in $41 \mathrm{~F} 4$ segregating families of common black bean.

\begin{tabular}{|c|c|c|c|c|c|c|c|c|c|c|}
\hline \multirow[b]{2}{*}{$\mathrm{R}$} & \multicolumn{2}{|c|}{ FPI } & \multicolumn{2}{|c|}{$\mathrm{PH}$} & \multicolumn{2}{|c|}{ NPP } & \multicolumn{2}{|c|}{ NSP } & \multicolumn{2}{|c|}{ SMP } \\
\hline & $\mathrm{F}$ & G & $\mathrm{F}$ & G & $\mathrm{F}$ & G & $\mathrm{F}$ & G & $\mathrm{F}$ & G \\
\hline 1 & 19 & 7.13 & 32 & 5.87 & 33 & 5.30 & 19 & 7.64 & 6 & 5.35 \\
\hline 2 & 32 & 6.96 & 16 & 5.50 & 19 & 5.17 & 1 & 6.66 & 19 & 5.33 \\
\hline 3 & 9 & 6.6 & 19 & 5.36 & 13 & 4.99 & 13 & 5.98 & 31 & 5.05 \\
\hline 4 & 10 & 5.91 & 20 & 5.28 & 3 & 4.74 & 3 & 5.33 & 33 & 4.86 \\
\hline 5 & 8 & 5.4 & 9 & 5.22 & 21 & 4.58 & 21 & 4.91 & 34 & 4.75 \\
\hline 6 & 24 & 4.9 & 3 & 4.92 & 6 & 4.41 & 33 & 4.51 & 15 & 4.44 \\
\hline 7 & 16 & 4.51 & 8 & 4.67 & 4 & 4.26 & 2 & 4.13 & 40 & 4.21 \\
\hline 8 & 30 & 4.21 & 2 & 4.43 & 31 & 4.12 & 22 & 3.83 & 21 & 4.01 \\
\hline 9 & 13 & 3.90 & 21 & 4.22 & 22 & 4.01 & 9 & 3.58 & 1 & 3.81 \\
\hline 10 & 23 & 3.64 & 1 & 3.99 & 1 & 3.86 & 31 & 3.36 & 4 & 3.61 \\
\hline 11 & 12 & 3.42 & 12 & 3.81 & 26 & 3.67 & 8 & 3.18 & 22 & 3.46 \\
\hline 12 & 2 & 3.22 & 13 & 3.63 & 40 & 3.49 & 17 & 3.03 & 3 & 3.30 \\
\hline 13 & 33 & 3.02 & 22 & 3.45 & 35 & 3.28 & 6 & 2.88 & 26 & 3.16 \\
\hline 14 & 36 & 2.81 & 17 & 3.30 & 17 & 3.08 & 16 & 2.75 & 17 & 2.98 \\
\hline 15 & 20 & 2.63 & IT & 3.08 & 5 & 2.91 & 34 & 2.62 & 13 & 2.82 \\
\hline 16 & IT & 2.47 & BE & 2.88 & 34 & 2.75 & 35 & 2.51 & 35 & 2.67 \\
\hline 17 & BE & 2.32 & BS & 2.72 & 38 & 2.61 & 39 & 2.41 & 41 & 2.53 \\
\hline 18 & BS & 2.20 & 23 & 2.54 & BE & 2.47 & 4 & 2.29 & 18 & 2.41 \\
\hline 19 & 29 & 2.08 & 10 & 2.35 & IT & 2.34 & 40 & 2.19 & 38 & 2.30 \\
\hline 20 & 41 & 1.96 & 7 & 2.18 & BS & 2.22 & 26 & 2.08 & 39 & 2.19 \\
\hline 21 & 1 & 1.85 & 33 & 2.03 & 8 & 2.11 & BE & 1.98 & 29 & 2.09 \\
\hline 22 & 17 & 1.74 & 30 & 1.88 & 16 & 2.01 & BS & 1.89 & 25 & 1.99 \\
\hline 23 & 37 & 1.64 & 39 & 1.75 & 27 & 1.91 & IT & 1.81 & IT & 1.90 \\
\hline 24 & 6 & 1.54 & 36 & 1.62 & 9 & 1.81 & 38 & 1.73 & BS & 1.82 \\
\hline 25 & 34 & 1.44 & 35 & 1.50 & 18 & 1.71 & 41 & 1.65 & $\mathrm{BE}$ & 1.75 \\
\hline 26 & 14 & 1.35 & 41 & 1.38 & 11 & 1.62 & 36 & 1.56 & 5 & 1.66 \\
\hline 27 & 25 & 1.26 & 6 & 1.28 & 28 & 1.53 & 32 & 1.47 & 2 & 1.58 \\
\hline 28 & 7 & 1.18 & 31 & 1.18 & 2 & 1.44 & 20 & 1.38 & 9 & 1.50 \\
\hline 29 & 21 & 1.09 & 5 & 1.08 & 36 & 1.36 & 27 & 1.30 & 8 & 1.42 \\
\hline 30 & 18 & 1.01 & 37 & 0.99 & 39 & 1.27 & 15 & 1.22 & 27 & 1.35 \\
\hline 31 & 22 & 0.93 & 15 & 0.90 & 15 & 1.20 & 5 & 1.13 & 28 & 1.27 \\
\hline 32 & 28 & 0.86 & 34 & 0.82 & 20 & 1.12 & 18 & 1.04 & 14 & 1.19 \\
\hline 33 & 15 & 0.79 & 40 & 0.74 & 29 & 1.05 & 11 & 0.95 & 30 & 1.11 \\
\hline 34 & 27 & 0.72 & 29 & 0.66 & 7 & 0.97 & 23 & 0.87 & 7 & 1.03 \\
\hline 35 & 11 & 0.65 & 24 & 0.59 & 41 & 0.89 & 29 & 0.79 & 16 & 0.95 \\
\hline 36 & 40 & 0.58 & 38 & 0.51 & 25 & 0.80 & 28 & 0.71 & 20 & 0.86 \\
\hline 37 & 38 & 0.50 & 4 & 0.45 & 23 & 0.71 & 30 & 0.62 & 36 & 0.78 \\
\hline 38 & 39 & 0.43 & 11 & 0.38 & 24 & 0.61 & 25 & 0.54 & 32 & 0.69 \\
\hline 39 & 3 & 0.37 & 25 & 0.31 & 10 & 0.52 & 7 & 0.46 & 24 & 0.59 \\
\hline 40 & 5 & 0.30 & 27 & 0.24 & 30 & 0.43 & 37 & 0.39 & 23 & 0.49 \\
\hline 41 & 31 & 0.23 & 26 & 0.18 & 32 & 0.33 & 24 & 0.30 & 10 & 0.38 \\
\hline 42 & 35 & 0.16 & 28 & 0.12 & 14 & 0.23 & 10 & 0.2 & 11 & 0.25 \\
\hline 43 & 4 & 0.08 & 14 & 0.06 & 37 & 0.12 & 14 & 0.11 & 12 & 0.12 \\
\hline 44 & 26 & 0.00 & 18 & 0.00 & 12 & 0.00 & 12 & 0.00 & 37 & 0.00 \\
\hline
\end{tabular}

than $5 \%$ and culminate in an increase of $2.8 \mathrm{~g}$ of seeds per plant.

\section{Heritabilities profile among segregating generations}

When relating the segregating generations as a function of broad sense heritabilities (Figure 1), it is observed that the number of pods and seeds per plant reveals superiority for this parameter in the $F_{3}$ segregating generation, that is due to the magnitude of heterogeneous families among themselves, that increase the total genetic variance and potentiate heritability, the plant height was benefited by the advancement of the $F_{2}-F_{4}$ generations, with the increase of the parameter over the generations and can be used as a selection criterion to increase the proportions of additive effects in progenies, in contrast, the total seed mass per plant was reduced according to the generations because the high genetic variation expressed in the $F_{2}$ population was predominantly controlled by dominance deviations that were minimized at the time of the selection generations.

In order to understand the total genetic trends among the characters measured along the segregating generations $F_{2}$, $F_{3}$ and $F_{4}$ the average Euclidean genetic distance was estimated using the broad sense heritability as a reference parameter, where the UPGMA grouping method was used to define the multivariate profiles of heritabilities and to construct a dendrogram to expose the distances (Figure 2). In this way, the profile I was composed by the number of pods per plant (NPP), number of seeds per plant (NSP) and seed mass per plant (SMP) measured in the $F_{4}$ segregating generation.

Profile II was composed by the first pod insertion height (FPI), measured in generation $\mathrm{F}_{2}$ and $\mathrm{F}_{3}$, profile III conjugates the number of pods (NPP) and seeds per plant (NSP) 
measured in generation $F_{2}$. The profile IV was responsible for grouping the number of seeds per plant (NSP) measured in $\mathrm{F}_{3}$ and the plant height $(\mathrm{PH})$ measured in $\mathrm{F}_{4}$, the profile $\mathrm{V}$ was formed by the number of pods per plant (NPP) and seed mass per plant (SMP) measured in $\mathrm{F}_{3}$ and plant height $(\mathrm{PH})$ measured in $F_{2}$. The profile $\mathrm{VI}$ was composed of seed mass per plant (SMP) measured in $F_{2}$, plant height $(\mathrm{PH})$ measured in $\mathrm{F}_{3}$ and first pod insertion height (FPI) measured in the $\mathrm{F}_{4}$ generation. These results indicate that the measured characters present additive and non-additive genetic relationships not only in the same segregating generation, but among the breeding generations of common black bean.

\section{Materials and methods}

\section{Conduction of study and experimental design}

The experiments were conducted in the agricultural crops of 2015, 2016 and 2017 in the municipality of TenentePortela RS located at Latitude $27^{\circ} 23^{\prime} 31.04$ "S and Longitude $53^{\circ} 46^{\prime} 50.71^{\prime \prime} \mathrm{W}$, altitude of 390 meters, where it presents humid subtropical climate of the Cfa type according to the Köppen classification, the soil is characterized as typical ferric aluminous red Latosol (Streck, 2008).

The experimental design consisted of augmented blocks using genotypes BRS Esplendor (BE), BRS Supremo (BS) and IPR Tiziu (IT) as controls in four replicates, the other treatments were uniquely arranged in the experiment, being the $F_{2}$ segregating generation (2015) formed by 33 common black bean populations, the $F_{3}$ segregating generation was composed of 69 families (2016) selected from the segregating populations, and $\mathrm{F}_{4}$ segregating generation was composed of 41 families from the targeted selection among the best $F_{3}$ families.

In all the agricultural crops the sowings were carried out in the second half of the month of November, being based on the system of direct sowing. The experimental unit was composed of two lines spaced 0.45 meters and five meters in length, using as standard the density of 10 seeds per linear meter, base fertilization constituted by $270 \mathrm{~kg} \mathrm{ha}^{-1} \mathrm{~N}$, $\mathrm{P}_{2} \mathrm{O}_{5}, \mathrm{~K}_{2} \mathrm{O}$ in formulation $10-20-20$, and for top dressing, 90 $\mathrm{kg}$ of nitrogen in the form of urea $(46 \% \mathrm{~N})$ was applied in the V4 stage. Preventive practices were prioritized to minimize the effects of weeds, pest insects and diseases that may influence the results of the experiments.

\section{Traits measured}

The traits of agronomic interest were measured in 10 random plants contained in the useful area of the experimental unit, these being:

First pod insertion height (FPI), measured through the distance between the soil level to the insertion of the first viable pod, results in centimeters $(\mathrm{cm})$.

Plant height $(\mathrm{PH})$, measured through distance between soil level to the last fully expanded trifolium, results in $\mathrm{cm}$.

Number of pods per plant (NPP), obtained by the magnitude of viable pods contained in the plant, results in units.

Number of seeds per plant (NSP), measured after the pod track, where the seeds contained in the plant were counted, results in units.
Seed mass per plant (SMP), seeds with no dirt were submitted to mass measurement, and after the mass was adjusted to $13 \%$ moisture, results expressed in grams (g).

\section{Statistical anlysis}

The data were submitted to analysis of variance at $5 \%$ of probability in order to test the model additivity, residue normality and homogeneity of the variances (Ramalhoet al., 2000). Subsequently, the Deviance analysis (LRT) was performed at $5 \%$ of probability by the chi-square test $\left(X^{2}\right)$, in order to verify the significance of the variance components and genetic parameters (REML), based on the model $y=X r+$ $Z g+e$, where $y$ : is the data vector, $r$ : are the effects of the repetitions assumed to be fixed, $g$ : are the genetic effects assumed to be random, $e$ : correspond to the effects of the residuals assumed to be random. Phenotypic variance $\left(V_{\mathrm{P}}\right)$, genetic variance $\left(V_{G}\right)$, broad sense heritability $\left(H^{2}\right)$, coefficient of determination of plot effects $\left(C^{2}\right)$, accuracy $\left(A_{c}\right)$, mean: general mean of the experiment were estimated. The BLUP (Best Linear Unbiased Predictor) predictions were carried out to obtain the components of the means and the ranking of the $F_{2}$ segregating populations and $F_{3}$ and $F_{4}$ segregating families $(R)$, as well as the percentage of predicted genetic gain $(G)$. With the broad sense heritability matrix, it was possible to estimate the mean Euclidean genetic distance, later the UPGMA grouping was done to construct the dendrogram, this approach was carried out with the purpose of defining the multivariate genetic profiles of the characters according to the segregating generations. The analyzes were performed using the softwares Selegen (Resende, 2016) and GENES (Cruz, 2013).

\section{Conclusion}

Superior genetic variability is established for the first pod insertion height and plant height in the $F_{4}$ segregating generation. For the number of pods, seeds and seed mass per plant, genetic contribution superior to the phenotype is expressed in $\mathrm{F}_{3}$ segregating generation.

The prediction of genetic value defines that the number of pods, seeds and seed mass per plant can be potentiated in $F_{2}$ segregating generation by selection of population 26, selection of $F_{3}$ families 64 and $49, F_{4}$ families 33 and 19.

Through the estimations and genetic predictions of the characters measured in the segregating generations $F_{2}, F_{3}$ and $\mathrm{F}_{4}$ it is possible to define six multivariate genetic profiles, these strategies being able to be used in quantitative genetic studies aimed at increasing the production of common black bean seeds.

\section{Acknowledgements}

The authors wish to thank the National Council for Scientific and Technological Development (CNPq) and the Coordination of Improvement of Higher Education Personnel (CAPES) for the support.

\section{References}

Carvalho IR, Pelegrin AJ, Szareski VJ, Ferrari M, Rosa TC, Martins T, Santos NL, Nardino M, Souza VQ, Oliveira AC, Maia LC (2017) Diallel and prediction (REML/BLUP) for 
yield components in intervarietal maize hybrids. Genetics and Molecular Research. 16: 1-12.

Carvalho IR, Nardino M, Ferrari M, Pelegrin AJ, Demari G, Szareski VJ, Follmann DN, Bahry CA, Souza VQ, Maia LC (2016) Genetic variability among common black bean (Phaseolus vulgaris L.,) accessions in southern Brazil. Aust J CropSci. 10(10): 1474-1483.

Conab (2018) Companhia Nacional de Abastecimento. Brasília. Acompanhamento da safra brasileira de grãos. v.5 - HARVEST 2017/18 - N. 6 - Sixth data collection, 2018.

Cruz CD (2013) GENES: A software package for analysis in experimental statistics and quantitative genetics. Acta Scientiarum Agronomy. 35: 271-276.

Federer WT (1956) Augmented (hoonuiaku) designs. Hawain Planters Rec. 55:191-208.

Melo LC, Peloso MJD, Pereira HS,Faria LCD, Costa JGCD,Díaz JLC, Abreu ÂDFB (2010) BRS Estilo: common bean cultivar with Carioca grain, upright growth and high yield potential. Crop Breeding and Applied Biotechnology. 10(4): 377-379.

MoretoAL, Ramalho MAP, Nunes JAR, Abreu AFB (2007) Estimação dos componentes da variância fenotípica em feijoeiro utilizando o método genealógico. Ciência e Agrotecnologia. 31(4): 1035-1042.

Moura AD, Brito LM (2015) Aspectos socioeconômicos. In: Carneiro JE, Paula Júnior TJ, Borém A (Ed.). Feijão do plantio à colheita, Viçosa, MG: Ed. UFV, 16-36p.

Ramalho MAP, Ferreira DF, Oliveira AC (2000) Experimentação em genética e melhoramento de plantas. Lavras: UFLA. 326p.

Resende MDV de (2016) Software Selegen-REML/BLUP: a useful tool for plant breeding. Crop Breeding and Applied Biotechnology. 16:330-339.

Resende MD, Ramalho MA, Carneiro P, Carneiro JE, Batista LG, Gois IB (2015) Selection index with parentes, population, progenies and generations effects in autogamous plant breeding. Crop Science. 56(2): 530-546.

Resende MDV (2007) Matemática e estatística na análise de experimentos e no melhoramento genético.Colombo, PR: EmbrapaFlorestas. 362p.
Rocha GSD, Pereira LPL, Carneiro PCS, Júnior P, Carneiro JEDS (2012) Common bean breeding for resistance to anthracnose and angular leaf spot assisted by SCAR molecular markers. Crop Breeding and Applied Biotechnology. 12(1): 34-42.

Rocha GSD, Pereira LPL, Carneiro PCS, Júnior P, Carneiro JEDS (2012) Common bean breeding for resistance to anthracnose and angular leaf spot assisted by SCAR molecular markers. Crop Breeding and Applied Biotechnology. 12(1): 34-42.

Rocha GSD, Carneiro JEDS, RezendeJúnior LDS, Menezes Júnior JAND, Carneiro PCS, Cecon PR (2013) Effect of environments on the estimated genetic potential of segregating common bean populations. Crop Breeding and Applied Biotechnology. 13(4): 241-248.

Schmutz J, McClean PE, Mamidi S, Wu GA, Cannon SB, Grimmwood J, Scoott AJ (2014) A reference genome for common bean and genome-wide analysis of dual domestications. Nature Genetics. 46(7):707-713.

Silva CA, Abreu AFB, Ramalho MAP (2009) Associação entre arquitetura de planta e produtividade de grãos em progênies de feijoeiro de porte ereto e prostrado. Pesq Agrope Bras. 44(12):1647-1652.

Streck EV, Kämpf N, Dalmolin RS, Klamt E, Do Nascimento PC, Schneider P, Giasson E, Pinto LFS (2008) Solos do Rio Grande do Sul. 2.ed. Porto Alegre. 222p.

Szareski VJ, Carvalho IR, Kehl K, Levien AM, Nardino M, Demari G, Lautenchleger F, Souza VQ, Pedo T, Aumonde TZ (2017) Univariate, multivariate techniques and mixed models applied to the adaptability and stability of wheat in the Rio Grande do Sul state. Genetics and Molecular Research. 16(3):1-13.

Szareski VJ, Souza VQ, Carvalho IR, Nardino M, Follmann DN, Demari G, Ferrari M, Olivoto T (2015) Growing environment and its effects on morphological characters and dieteticsoy. Revista Brasileira de Agropecuária Sustentável. (RBAS) 5(2):79-88. 